\section{JUDGMENT DAY}

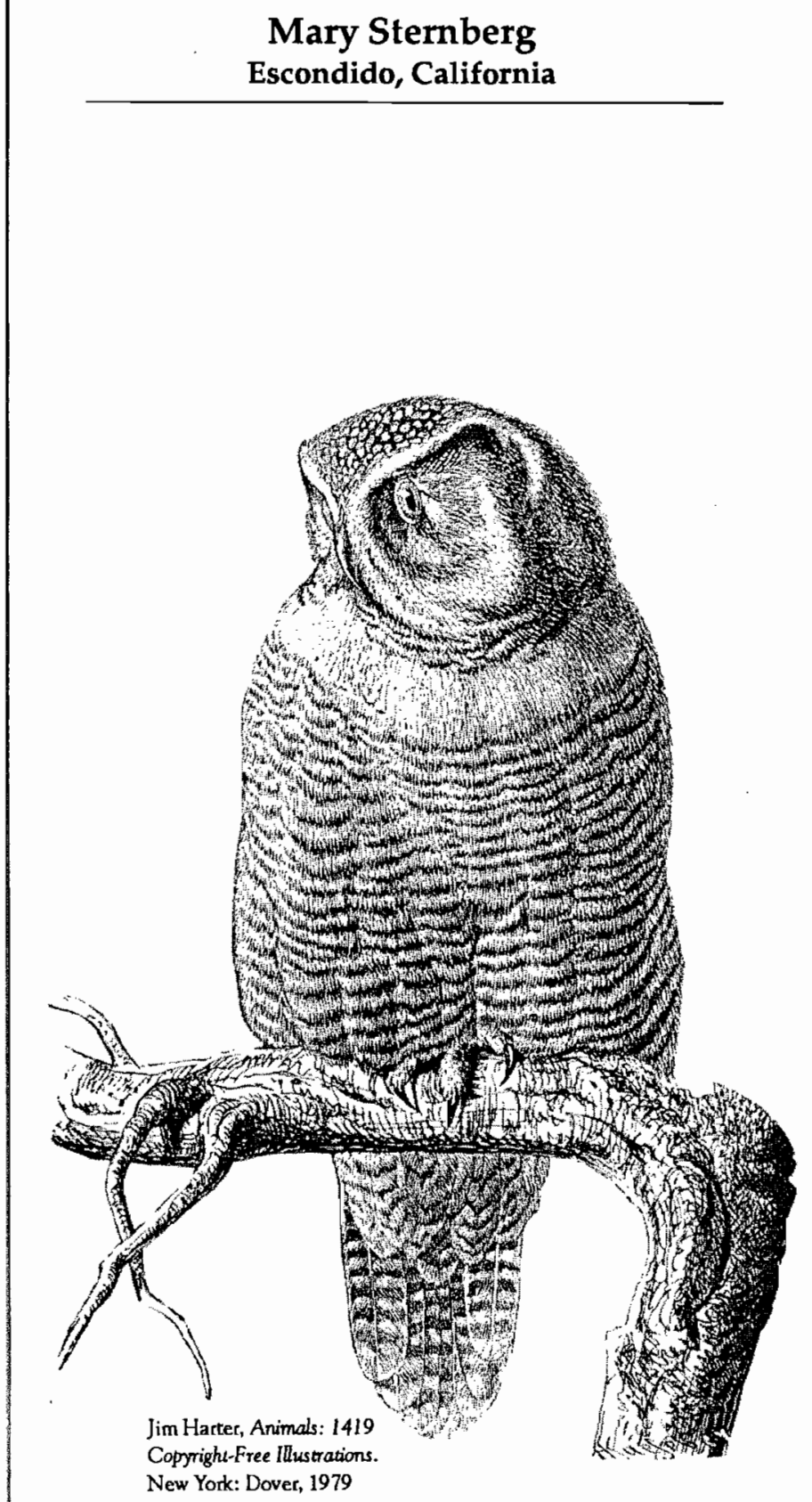

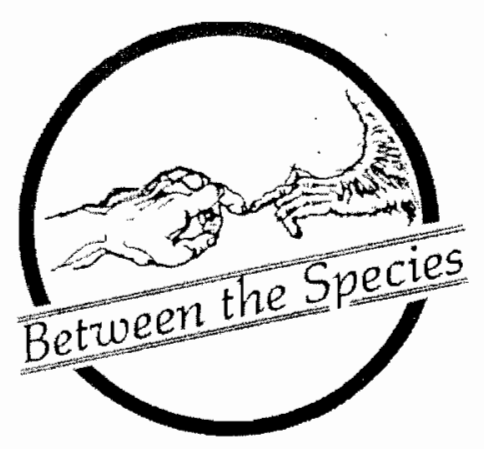

The bloated bodies rolled and bobbed around him as he stood waist-deep in the stinking water. As far as his eyes could see it was the same, and he had been standing here forever. Was this the hell that his minister talked about? He could feel himself slipping on the slime at his feet. He knew that if he ever went under, it would be the end. He must get away, must run, but as he tried to move, his legs seemed held by the filthy liquid. It was like trying to run through a sea of mucilage. He screamed, he pulled, he lifted his legs and, with all his strength, tried to walk. He was held fast. He let out another scream that echoed shrilly across the muddy water.

As a sharp scream rent the still air, Tom McGee said to his wife, Sadie, "Oh Lord, here comes Jeremy again."

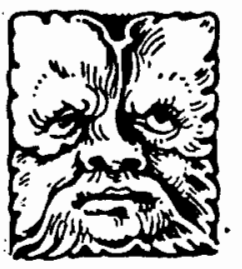


Like everyone else on their street, they had been sitting on their front porch after supper trying to catch a little breeze to relieve them of the humid heat of the Missouri summer day.

Their little town of Adams was a quiet place. Nothing much ever happened. At one time, the train had come through on its way to Moberly, and it would even stop at Adams if there were passengers to take on or let off. It had been exciting to go down to the station and watch the train roll by, its great iron wheels clicking and its whistle blaring. There was always the hope that someone might be getting off.

Now the old "Katy Line," as it was called, had been discontinued, and the train tracks were overgrown with grass and weeds. The poople of Adams had nothing much to talk about except their ancestors, Jeremy Peabody, and their one claim to fame, the Great Storm.

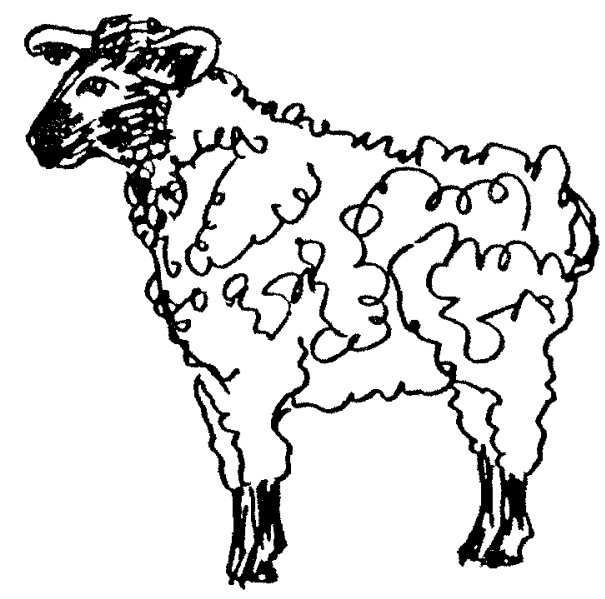

"I'll stop him, Roy," yelled Tom, as he ran off the porch to grab the screaming Jeremy who was running fast down the sidewalk.

As he held onto the young boy, Jeremy began to sob and finally to awaken and quiet down.

Roy Peabody took hold of his son's arm to lead him gently home. "Thanks, Tom," he said, "another one of Jem's nightmares. We thought he was better, but he still gets these ever so often."

"Sorry, Roy, hope he'll get over it soon," and Tom and Sadie watched the father and son walk slowly home.

"I wonder if he ever will get over it," said Sadie. "It's been almost two years, and he's not the only one. There's plenty of folks around here won't get over it."

And their minds went back to the day of the storm.

Jeremy stood there, head down, kicking at the gravel in the driveway. "Gollee, Ma, I only just had a bath yesterday," he said.

"In this heat even a couple of baths a day wouldn't hurt a nine-year-old boy. You know you have to look nice for the church picnic."

It seemed to Jeremy that he was the only one in town who didn't like church picnics. He'd a lot rather stay home with his newly-hatched banty chicks. He loved to watch the mother hen teaching them how to scratch for bugs and see her spread her wings to protect them at the least sign of danger. $\mathrm{He}$ thought she was the smartest, best mother he'd ever seen, and it made him mad when folks said that chickens were dumb. His hen and rooster had more sense than a lot of people he knew, but he wouldn't dare say that to anyone. 
Aside from his chickens, Jeremy was also raising a fine Hampshire pig, named Arthur. He was happy to let these animals take up most of his time during the long hot summer days, and everyone could see that he had a special way with them.

Once he had tried to tell his Dad that his animals understood everything he said to them and that he understood them, too, but his Dad only looked at him kind of funny and said, "Jem, don't you ever forget that they're only animals put on the earth for one purpose and that's for our use. You need to get out and play with the other kids more."

The friends he used to have - Billy Bob and Estil - now had rifles, and all they ever wanted to do was go hunting. Once when he went with them, Estil hit a rabbit. When they went to get it, it was still alive, its hind quarters bleeding and paralyzed. The rabbit looked at them with scared eyes and tried to pull itself away with its short forelegs. "My gosh," said Estil, "it ain't all dead," and he shot it again at close range turning the soft brown body into a mess of bloody innards.

Jeremy left, pretending he had to get home to feed his pig. He never went hunting again.

Once he had tried to tell his Dad that his animals understood everything he said to them and that he understood them, too, but his Dad only looked at him kind of funny and said, "Jem, don't you ever forget that they're only animals put on the earth for one purpose and that's for our use."
This day of the picnic was one of those still, hot days that seem to follow endlessly one after the other during a Missouri summer. Once the sun set in, nothing moved that didn't have to. Dogs slunk under porches where they stayed all day sleeping fitfully between flea bites. Cattle in a field at the edge of town huddled together in the sparse shade of a lone tree, so bent over by last year's ice storm that it seemed to lack the spirit ever to stand erect again.

Few people were on the streets. Business men, at home after their noon dinners, rested in hammocks or swings on the porches, fanning away flies with the sports sections of the newspaper.

Jeremy's father, Roy Peabody, who ran the local tractor agency, had just announced to his wife, Emma, that the temperature was 102 in the shade, and then went inside to listen to his radio.

Emma wiped her wet forehead against her upper sleeve and went on with her cleaning, wiping the plastic tablecloth which was losing its gleam and floral pattern but was still all right for every day.

She wondered why the day of the church social always had to be the hottest one of the year, but at least she had prepared most of her food the night before. The chicken was fried and stored in the cooler. The slaw was made, and she had even baked her specialty, a peach cobbler. Nothing left to do but slice some tomatoes and remember to take some thick yellow cream along for the cobbler. The heat would let up some later on, but hot or cool everyone would sure eat, she knew that. Some of the best cooks in the country belonged to her church.

The country club was no more than a large frame building situated on the bluff above the Osage River, but it served as a meeting place for church groups, card clubs and other local organizations such as the P.E.O.'s and the D.A.R.'s. Tonight a local band would supply music so that the young people could dance. 
The adults rarely danced. The main activity for the men was court croquet which was as different from lawn croquet as professional tennis was from a child's badminton game. Played on a large, hard, flat dirt court with wickets set far apart, the men had developed the game into one of skill and precision. Their mallets were totally unlike those used for lawn croquet. Court mallets had heavy wood heads banded in iron and short handles so that they were held low to the ground with the player squatting to one side of ball and mallet rather than standing astride them. It took strength, a keen eye and years of practice to become adept at court croquet. But how the men loved it! Big electric lights had been installed so that the teams could play at night. The competition was stiff, but somehow always good-natured. No one ever gor mad it seemed.

The women, after cleaning up the picnic dishes and taking left-overs back to the cars, liked to sit on benches near the courts and partly watch the men and partly "visit." There was always so much to talk about. In this time before television, conversation was still a family and a social art. People loved to get together and talk. The women's talk was about children, new recipes, new dress patterns, with a goodly amount of gossip thrown in to keep things lively.

Emma was thinking how she would regale them with the tale of her last permanent, how she almost fainted in the heat and the trial of sitting so long under the great permanent wave machine. Her face had gone white and her eyes had rolled up, so they began throwing cold water on her until someone had hollered, "Ya better quit that. Do you want to electrocute her?"

The idea of getting electrocuted brought Emma around, and she managed to sit through to the end, but it had been a terrible experience to feel herself fainting, the heavy curlers pulling on her scalp as she nearly went over with the machine on top of her.

"Hey, Emma, did you hear the news?" called Roy. "Maybe we better not go."

"What do you mean, 'not go'? What am I sposed to do with all that food?"
"Well, it sounds mighty bad to me, but maybe it won't hit around the club house."

\section{'What won't hit? What are you talking about?"}

"There's been a bad electric storm up near Shelbina - uprooted trees, turned cars over and did all kinds of damage; it's headed our way."

\section{"Sounds more like a cyclone or earthquake to me."}

"Well, whatever it is, they're issuing warnings, telling people to stay home and batten down everything that's loose. It may hit us before we even have a chance to go. I think we should at least keep listening to the radio for awhile to see what's going on."

"Aw, it might go right on past us like it did last time," said Emma. She so wanted to go. She had made a new dress, and it was real becoming she thought, kind of a bluish green cotton polka dot material that matched her eyes and complemented her brown hair. It made her look cool and fresh, and she was all set on wearing it. She looked at the sky and said, 'Why, it doesn't even look like rain. I'll call Sue Ann and see what they're going to do."

"Just cause Sue Ann and Henry want to get blown away doesn't mean I do," said Roy.

But Emma was already on the 'phone. "Yes, that's what I think, too, Sue Ann. I'll tell Roy."

"Sue Ann says they heard the storm's gone on past and is headed out west of here; says everybody she's talked to is going tonight."

"Well, that sure isn't what I heard," said Roy, "but if you're bent on going, I'll go on in and take my shower."

"Yeah, don't worry about it, honey," and she called to Jeremy but found he was all bathed and dressed, and, as she looked at him, she was proud of him. The curls of his red hair got even tighter in the humid weather, and there was a certain appealing expression in his blue eyes that always won her over. 
He was tall for his age and strongly built, but she worried about him. He was too much of a loner. "Maybe he'll grow out of it," she always said.

When they reached the club grounds, the tables were set up outdoors and women were busy laying out the food. Children were hollering and chasing each other and getting underfoot. Sue Ann grabbed her daughter's arm and said, "Eliza Jane, I want you to take your friends and go way over yonder behind the club house to play where you won't be knocking into the tables, you hear?" told.

The kids looked disgruntled but did as they were

The men went out to the courts to check the wickets and ground. A couple of them got out the roller to roll down a few footprints. "Do you reckon some of those kids have run across these courts again," said Al Henshaw. "I swear I'll skin him alive if I ever catch one."

Emma and Roy got their food laid out along with the rest. How good it all looked - two large baked hickory-smoked country hams, one at each end of the four long tables that had been pushed together, and in between were mounds of fried chicken, baking powder biscuits, beaten biscuits, homemade potato salads and slaw. Beefsteak tomatoes from home gardens lay sliced thick and ripe, their juicy redness gleaming in the sun. And the desserts there were pecan pies, Jeff Davis pies, peach and cherry cobblers, and a Prince of Wales cake standing tall and rich. Nobody would go home hungry this night!

Emma was already basking in the praise of her new dress. "Wasn't hardly any trouble to make," she said, "cut it out one day and stitched it up the next."

There was a good-sized crowd there, all the people Emma liked best from the church: Pete Hill the banker and his wife Josie, who was rushing around, as always, making sure that everything was done just right; Allen James who owned the drugstore was there with his wife and kids; the Bartletts, Pettigrews and a bunch of others as well as, of course, their minister and his wife and children.
"Are we about ready?" called Sue Ann. "Shall I ring the cow bell?"'

"You better, yes, we want to eat and be finished before it gets dark," said Emma, looking at the sky which seemed to have grown overcast and threatening.

As Sue Ann reached for the bell, the children came running from the other side of the club house screaming, "Ma, Ma," said Eliza Jane, "there's such a big wind starting up over where we were that" - but she got no further before the wind began to hit.

"Everybody grab some dishes of food and run to the clubhouse," Roy hollered, "and hurry."

Some grabbed dishes and some just ran, for the sky was darkening and the wind getting stronger. Paper napkins, plates and cups were flying through the air, and one of the tables looked on the verge of tipping.

Carol Belanger Grafton,

Old-Fashioned Animal Cuts.

New York: Dover, 1987

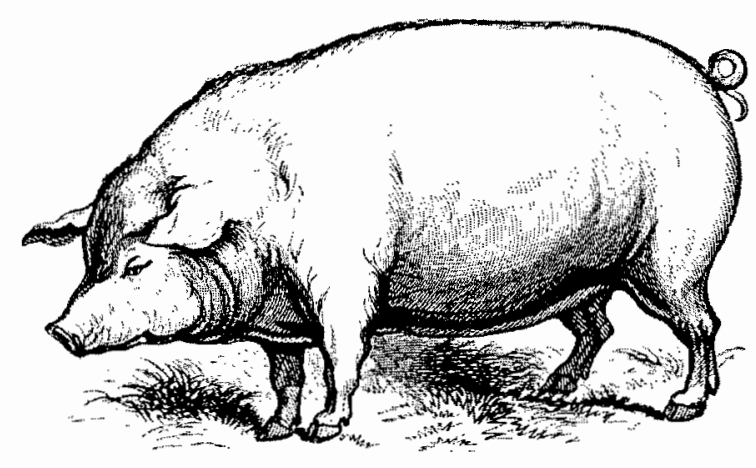


"My gosh, Roy, what's happening?" yelled Emma.

"Just take your chicken and get into the clubhouse - fast," said Roy.

Once they were all inside with the door tight shut, they turned to look out the windows. One by one the picnic tables were overturned, as though some giant hand had lifted and thrown them, strewing food into the air.

"Is it a cyclone, Mom?" yelled one little boy, beginning to cry.

"Now just you hush, Bill, it's only a big wind that will die down soon and we're safe in here," said his mother.

A loud shriek silenced them. "My baby, my baby, she's not here," cried the minister's wife. "She was right with me and the other kids when we ran, but now she's not here. Sarah, Sarah, where are you?"

"Anybody seen the little girl?" called Al Henshaw. "Look all around you. Maybe she's scared and back in a corner somewheres."

"She must be still outside," said the minister, and with that he tore open the door and ran out.

Children began crying, and mothers, ready to cry themselves, tried to comfort them. The minister's wife was almost hysterical. Roy saw that something needed to be done.

"Listen to me, all of you," he said. "We've had a bad scare, but we're safe now, and I'm sure the Reverend will be back with Sarah soon. While we wait, we can pray and we can entertain the children. Above all, we don't want to panic. That wouldn't help anyone. We have enough food in here to feed us all. We can sit down in a big circle and pass it around and try to enjoy the good things that so many ladies went to a lot of trouble over."

One by one they sat down on the floor that had been cleared for dancing. The chairs had all been taken outside for the picnic, and the Lord only knew where they'd been blown to by now. The wind still howled. They could hear it rattling the boards on their clubhouse as well as feel great gusts of it hit time and again against the sides of the building.

But they were hungry, so they began to eat, and it cheered them up.

"Did anyone remember to bring in the soda pops and the punch?" someone asked.

"Here's the gallon jug of punch, but that's all I see," said Sue Ann. The gallon was passed around along with the two or three glasses that had been found in the clubhouse.

"When the punch is gone, we can always drink water," said Emma.

"Fraid not," said Tom McGee, "I tried to wash these glasses and no water came out of the tap."

"Water line's probably busted, but they'll fix it soon," said Roy. "Let's get back to the food. One thing we seem to have plenty of is fried chicken and country ham, and boy, do they taste good! Who brought the ham? You, Josie?"

"Sure did - one of our own hogs that Sam butchered and cured," she answered.

Just then came a crash of glass as the window pane of one of the windows fell in splinters on the floor, followed by a blast of wind that sent them all over to the other side of the room out of its path.

"Takes some strong wind to do that," said one of the men. "We better try to board it up before it blows the whole side of the building out. Can't let the wind catch a hold like that."

Boards and nails were found in the storeroom, and it took four men, holding each other up and leaning against the wind with all their weight to get the boards nailed into place.

"This is sure no usual storm," said Roy.

"I'm worried about our minister," said Tom McGee. "He's been gone nearly an hour. Do you 
think we should go and look for him?"

They looked at the minister's wife. She seemed dazed, her eyes staring straight ahead as she huddled back in a corner, her thin arms around her two sleeping children.

"I don't like the way she looks, almost like she's in shock," said Tom. "We better do something."

"C'mon," said Roy, "we'll go look for him. The other men better stay here with the women and kids."

By now the noise of the wind was so loud they could barely hear each other. It tore at the building in ferocious gusts that rattled and shook the beams and floor boards. Suddenly, they heard the ripping, rending sound of wood, and someone yelled, "The porch is going! It's getting ripped right off the building." And with one final wrench that felt as though the entire building would split, the front porch was gone.

"My God, do you think we can go out in this?" said Tom. "How could we even stand? We'd be blown away just like the porch."

"Not only that," said Roy, "but it's dangerous to open the door. It would give the wind enough of an opening to tear this whole place apart. No, we've got no choice but to stay here and to keep on praying."

$\mathrm{He}$ looked around the room at the frightened faces. The children, sensing the fear, were clinging to their parents and sobbing. The mothers, so neatly dressed a short while ago, now looked haggard dresses torn and dirty, hair straggling in wet strands about their worried faces. The men moved about among them trying to console and reassure, but their voices were so deadened by the noise of the shrieking wind that no one seemed to be paying any attention to them.

Jeremy, his ear close to the floor boards, said to his mother, "I keep hearing someone crying, sounds like it's coming from right here," and he pointed to a knot-hole in the wood.
"You're just hearing the wind noises, Jem," she answered. But she put her ear to the floor just to please and distract him. Sure enough, it did sound like the cries of a human voice. "Roy," she called, "come here quick."

After listening for awhile, Roy got up, looking puzzled. "It sure sounds human, but who could be under this floor. Anyone down there in that open space would sure have been blown away long ago."

"But it is somebody, Daddy," said the boy. "It's a kid; I just know it."

Others came to listen and someone said, "Could it be the minister's child, or even the minister himself? Nobody else has gone out; it's got to be one of them, but it sounds like a child."

Roy, with his mouth over the hole, hollered as loud as he could, "Is that you, Sarah? Call back and answer us."

As they listened, no answer came other than the continued crying sounds, sometimes lower, sometimes higher, but definitely, it seemed, like cries of pain.

"We can't let the kid suffer," said Roy. "Give me that hammer, Al. We'll have to lift this short board and have a look. Then we'll figure out how to get whoever it is out of there. Get a flashlight, too, somebody."

When the board was removed, Roy tried to see through the narrow opening. The flashlight was so dim that it cast only a small, weak glow into the dark recess.

"Flashlight's no damn good," said Roy, throwing it to one side and reaching his hand down through the opening. He pushed farther and farther into the hole until his entire arm was in up to the shoulder.

A shudder ran through Emma as she watched. She wondered if she'd dare to put her arm into that dark mystery. "Most anything could be down there," she thought 
As Roy felt around below, he became more and more puzzled. Everyone crowded around him, watching and saying, "What is it? Can you tell?"

Roy kept saying, "Well, I'll be damned." Then he slowly pulled his arm back up through the hole. His hand and arm were covered with blood.

"Dear Lord," said Emma, "What happened? You're bleeding so bad!"

Roy looked at his arm and seemed as surprised as anyone. "That's not my blood," he said. "It's from the thing down there. I'm not hurt one bit, but whatever's down there is hurt plenty, and I think it's a hog."

"A hog!" they all yelled in chorus. "What's a hog doing down there?"

"I don't know, but I could feel its trotters and its throat which seemed to be part slit open. It's still yelling like a human baby."

"Let me smell your hand," said Jim Buford, pushing toward him. "I've killed many a hog and cured and smoked them, too. It's not a smell you forget once you've stuck a pig." Coming closer for a sniff, he said, "That's pig blood for a fact."

"There's a rifle in the storeroom. I'm gonna get it," said Roy, "and put that hog out of its misery."

Jeremy, who had been the first to hear the hog's cry, said, "Would you do that if it was a kid? I'm glad I ain't that hog."

"Jeremy, what an idea!" said his mother. "Of course, if it was a child, the men would get it up and we'd do all we could to help it. But it's only a hog."

"But it cried like a baby," said Jeremy. "Don't that cut in the hog's neck hurt same as it would a kid's?"

"Might as well save your bullet, Roy," said Jim. "The thing's quiet now, must have bled to death."

"Oh dear Lord, save us," screamed Emma who had turned to look out the window. "It's Armageddon for sure!" and she got down on her knees to pray.
As the others reached the front window, the avalanche of water hit. Surging over the river bank, it rose ten feet high in a great dark, muddy wall that seemed to be carrying with it what looked liked hundreds of mutilated bodies.

"Let me smell your hand," said Jim Buford, pushing toward him. "I've killed many a hog and cured and smoked them, too. It's not a smell you forget once you've stuck a pig." Coming closer for a sniff, he said, "That's pig blood for a fact."

Instinctively, they all fell flat to the floor. As they lay there, they didn't have long to wait. The water hit with a solid reverberating smack against the front of the clubhouse, sending a shudder through the floor and walls that felt as though it would lift the building from its foundation.

The structure swayed and pitched, rolling its screaming occupants to the far side but somehow holding to its base in a seemingly determined effort.

They lay clinging to one another, too frightened to cry, too frightened to move, only waiting for the next impact.

Then they became aware of the sounds. What were those terrible noises? Screams, cries and moans of an unearthly quality pierced the air.

"What is it, Momma?" asked Jeremy. "Is that a whole bunch of people? Look, something's in front of the window!"

Almost afraid to look, she slowly turned her head, trying to peer through the murkiness. She could hear the water churning and roiling beneath them. Thank 
God the clubhouse was built on high ground and sturdy foundations. The water hadn't reached the floor boards yet, but whatever those large objects were that she got a glimpse of as the water overflowed the banks, were now hitting and banging against the house and foundations like so many tree logs released to be carried downstream.

The uncanny sounds continued. She called to Sue Ann lying near her, "Are those people screaming? They must be hurt badly and calling for help."

"I expect they're drowning, trying to cling to the house," said Sue Ann. "Oh God, I don't know any more than you do, but the sounds they are making are like nothing I've ever heard. Sounds like the cries of the damned. Maybe you're right, maybe this is Armageddon."

"I saw it, Ma," shouted Jeremy, "I saw what's hitting the clubhouse - it's cows!"

"Cows, oh, Jeremy, lie down. You know it couldn't be cows." But as she listened, she wasn't so sure. Some of the sounds did seem to be like the tormented lowing of cattle. Once when she was a child, she had seen a frisky calf get caught in a threshing machine. Its agonized cries that kept up until her father came and shot it, were not unlike what she was hearing now.

She looked again toward the windows. Dark shapes were banging against them.

"There goes a front window," someone shouted, and with that the water poured in, sending everyone to his feet, holding on to each other, to the walls, to anything they could grab.

The water wasn't deep and had apparently reached its level, but the smell! How it stank! Dark muddy brown, it carried with it all manner of refuse and filth. Swirling about their feet and legs, the water assaulted their nostrils with the fetid stench of decay. The contents of a modern Aegean Stable seemed suddenly dumped around them. Not only was the water filled with excrement, but solid pieces of they knew not what caught at their feet and legs, clinging until they reached down to pull them loose.
Jeremy, waist deep in the filth, held up something a long strip that looked like animal hide. "Is this from a cow, Ma?" he asked.

His father picked him up. "Don't touch any of that dirty stuff, Jem. I'll hold you up above the water."

"We can't stay in this," sobbed Emma.

"Just take it easy," said Roy. "We're still alive, and the storm seems to be letting up. We have to stay here til the water recedes. It's over our heads outside."

Roy looked around. Everyone appeared demented. Sobbing and holding crying children, he feared they might give way and fall into the water.

"I'm going to lead us in prayer," called out Roy. "Lord Jesus, if this be the Day of Judgment, please forgive us our sins and our frailties. Mostly we are good people who have worked hard and tried to be good to others of our kind. Sometimes we're selfish and greedy; sometimes thoughtless and mean, but we try to follow your word. Forgive us now for the times we have failed you, and help us in this hour of great need. Amen."

"Amen and help us, Oh God, help us," they chanted over and over.

Someone near the window called out. "The water's not flowing in any more, but it's so dark by now I can't see what's happening outside. The wind's let up, too, so if we can just hold out til morning, we can get out of this hell hole."

"How can we stand in this filth all night," cried Emma. "There's some disgusting stuff stuck to me, and any way I turn I only get into more of it. What is this evil dirt we're standing in?'

"I keep telling you it's from cows, Ma," said Jeremy.

"I've heard you, Jem, but that makes no sense. In all the country club acreage there's no pastureland. There's never been any cows up here. All the pastures are down in the low farmlands."

"I just wonder who could've killed all those cows," said Jeremy. "These have their guts pulled out and their 
hides ripped away."

"Quiet, you all," said Roy. "I think I hear something," and he called to the others, "let's be real still; I think there's something on the roof."

As they listened, they could hear ripping, tearing sounds coming from a far corner of the roof. They waited; they strained to see in the darkness. The noises kept up. Something was working at the shingles trying to pull them loose.

"They must've sent help from town, and they're coming in through the roof," said Roy.

\section{The bloated bodies and partial bodies of cows, sheep and pigs surrounded them, held in the deep mud of the receding water. Most had their throats slit, their heads thrown to one side, hanging by neck hide; their tongues lolled forward and their great glassy eyes stared.}

Now the noise grew louder. Whoever was up there was stamping and beating at the board beneath the shingles, trying to break it through. Finally, there came a loud crack of splitting wood, and they heard the voice of their minister.

"Tom, you're the biggest fellow here," said Roy, "if you'll hold me on your shoulders, I'll go up and help the Reverend make that hole larger."

Working until their hands were raw, the two men finally made a hole large enough to admit a human body. The Reverend's wife and kids went up first, supported on Tom's shoulders with the Reverend pulling them through. One by one the other women and kids went first, followed by the men. Last, Tom himself was pulled through.
Since the roof was almost flat, they could lie on it until morning. The wind had stopped and the half moon was casting eerie shadows on the water around them. Or were they shadows? No, some kind of large shapes were moving in the dark water. The stench remained. Hanging in the hot, heavy air, it was as though all the world had been turned into an undrained cesspool.

But they were dry; no longer did they have to stand in the putrid water. They thanked God and tried to find places to rest on the gently sloping roof.

Only the minister's wife was sobbing quietly. The minister had said, "I couldn't hold her, the wind and water tore her from my arms and she was carried away. We've lost her; we've lost our baby. The only thing that saved me was a tree that stood against the storm. I was able to climb onto one of its branches and cling there 'til the wind stopped."

Bit by bit people got their children quieted and then lay down themselves. Everyone was so physically and emotionally drained that they soon slept, the men lining up around the roof edges so that the children couldn't roll off.

Jeremy lay awake after all was still, many thoughts running through his head. Had the storm hit their house? Were his chickens and other animals killed? Why didn't anyone come to save them? At last, exhaustion overcame him, too, and he knew no more until he was awakened by loud voices.

It was daylight, and they could now see. "What could've happened?' they were all asking. A nightmare scene lay before them, surely the invention of a satanic force uglier than anything the human mind could devise.

The bloated bodies and partial bodies of cows, sheep and pigs surrounded them, held in the deep mud of the receding water. Most had their throats slit, their heads thrown to one side, hanging by neck hide; their tongues lolled forward and their great glassy eyes stared. Some were partially stripped of their hides; others had great chunks cut from their bodies in neat systematic slices. Many had little left but their bony structure, strands of pale white flesh still clinging to the ribs. 
Curiously, the neck of one hog still held the slaughtering knife. The butcher had driven it deep enough to catch into the neck bone, and there it stuck to tell the loathsome story of the slaughterhouse.

"Did the storm do that to these animals, Dad?" asked Jeremy.

His father only stared in disbelief, unable to answer.

Most of the women had taken one look and turned away. Some were vomiting, others crying.

Emma seemed to be turned to stone. She, too, couldn't speak.

And so they remained, staring in mute shock, the animals' eyes looking back at them.

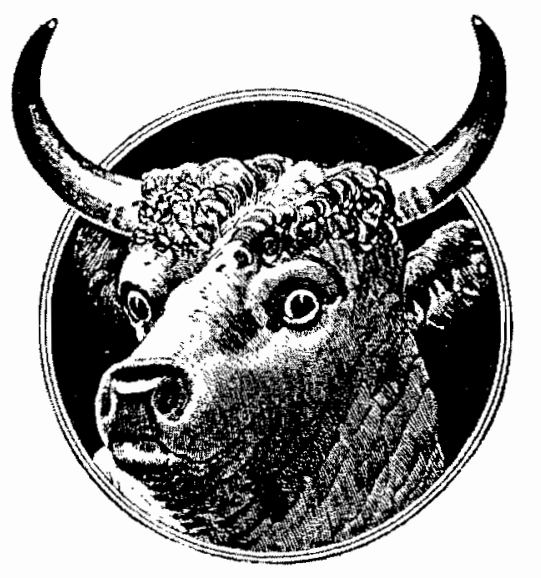

Carol Belanger Grafton,

Old-Fashioned Animal Cuts.

New York: Dover, 1987

\section{THE HORSES OF RETRIBUTION}

Now through the dust they comehorses black as the heart of rain; their necks are scarred, their foreheads burned

with mystic anger and love.

And we can soak their running power into our flesh, becoming black water; and locked into the body of God we can evoke the flashing days to teach us torrent of total pleasure; we can be swept to meadows of praise.

And geese we listened to at the dead door of the subconscious till all fear broke, and like them we rose and flew, cry now across the marshes of the years with ancient pity and perceiving woe ;stretching our black-beast sinews we pursue

and overtake these birds, speed under them in joy;

and where we come upon the murdered fawn

we dabble our hooves in the clean blood, and swear to avenge with an unspeakable pain

all violations of nature's good.

George Abbe 